\title{
On Collecting and Publishing the Albanian Oral Epic
}

$\mathrm{T}$ he aim of this paper is to examine how the Albanian epic known as the 'Cycle of the Frontier Warriors' has been presented in Albanian folklore collections. I will examine seven written versions of the song 'The Wedding of Ali Bajraktari', which belongs to this epic cycle. The 'Cycle of the Frontier Warriors', has been an object of collection since the beginning of the twentieth century. There are now dozens of volumes published, but the studies published to date concentrate on historical, thematic and comparative rather than contextual and textual issues.

\section{Introduction}

I understand the term 'oral epic' to refer to long narrative poems that, in an elevated manner, recount the struggles of legendary or historical heroes. This is, more or less, the definition that has come down to us from Aristotle, who formulated it in the context of Homeric epic. Oral epics have continued to be thought of in this manner. This definition is still true regarding the thematic content of epics. But the definition has evolved, and today there are many different definitions of epic. According to Lauri Honko, oral epics are performance traditions, and performance is to be understood as a multidimensional communicative and emotional experience that cannot be encapsulated in a simple verbal text (Honko 1998a: 9). This means that the text or content alone do not suffice in defining an epic. According to John Miles Foley, the epic is a master genre of the ancient world (see Foley 2005) and he elaborates further the ways in which epic played a major role in ancient societies. Barbara Graziosi defines epic as a genre by means of many different criteria, including the mode of discourse, the length, its relationship to other genres, subject matter, theological framework, national or ethnic significance, elevation of diction, mode of composition, mode of dissemination and metre (see Graziosi and Haubold 2005).

The definition of epic in Albanian scholarship has not evolved very much, since the commencement of collection, when researchers mainly focused on its content, origin, length, composition and metre, and sometimes its interpretation, as well as its influence on other national epics. The epic songs have been treated as texts, not as performances or as multidimensional communicative experiences. Alfred Uçi (1986: 3 ) suggests that epic should considered as a special folk genre, possessing relevant features such as heroic and legendary aspects, combined with a specific method of artistic expression, which makes it different from other forms of oral poetry. Qemal Haxhihasani defines epos as 'related to the great and originating epochs of the history of our nation, where are gathered in a unique work the entirety of its soul, culture and history' (Haxhihasani 1991: 33). The problem of definition is always related to the issue of authenticity, origin, authorship and autochthony.

Albanians also live as discrete ethnic populations in neighbouring countries. The Albanian national epic, known as the 'Cycle of the Frontier Warriors', is still sung by elderly men playing the one-stringed instrument, the lahuta. The epic songs which make up this cycle are literary reflections on legends portraying and glorifying the heroic feats of warriors of the past. The leaders of the band of thirty warriors, or agas, are Gjeto Basho Mujo and his brother Halili, who inhabit a frontier region between the Ottoman Empire and Austria-Hungary. While the Bosnian Slav epic seems to have died out as a living tradition, the Albanian epic is still very much alive. Even as the twenty-first century marches on, one can still find a good number of lahutars in Kosovo, in particular 
COTMET E KOMISJONIT TE KREMTIMEVE

TET VET-OEVERIMIT

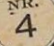

IISIREPI \& ROIBIT
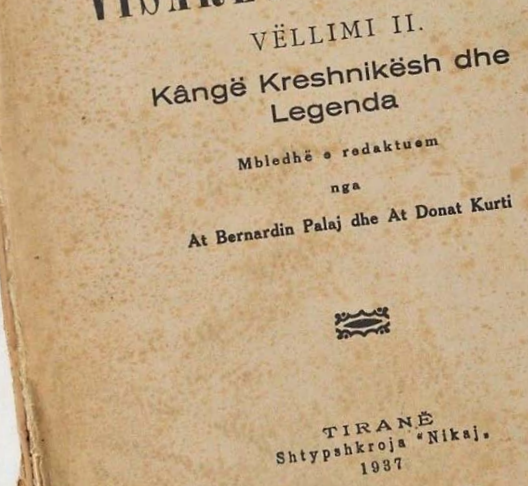

Frontispiece of the first edition of Visaret e Kombit ('Treasures of the Nation'), published in 1937.

in the Rugova highlands west of Peja, and in northern Albania, as well as a few singers in Montenegro, who are able to sing and recite the heroic deeds of Mujo and Halili and their thirty agas as part of an unbroken oral tradition. One can safely assume that these elderly men constitute the very last traditional native singers of epic verse in Europe (see Elsie and Mathie-Heck 2004: xi).

The folk epic songs of the Albanians were first recorded by Albanian Franciscan priests and scholars working in northern Albania at the end of the nineteenth and beginning of the twentieth century. They collected different folk material from the villagers who lived in those remote and mountainous zones.

This coincided with a growth of national awareness in many European countries. On the 25th year of the independence of Albania, in 1937, the work of the Franciscans and Jesuits in Shkodra (Albania), were published in a series of books called Visaret $e$ Kombit (The Treasures of the Nation).

At the same time, in the 1930s, Milman Parry and Albert Bates Lord from Harvard University visited the Balkan countries and recorded the long epic verses. While in Bosnia, they recorded several
Albanian songs from the Bosnian singers who sang in both languages (see Kolsti 1990). Some of these bilingual singers were Albanians (Elsie and MathieHeck 2004: xii).

During the period of communism in Albania, folklore, that is to say, the country's national heritage, epics included, was researched, recorded and studied by scholars, whose academic institutions published volumes and series of monographs. This cultural content had almost the same status as national heritage in Kosovo, where Albanians comprise the majority of the population. But when Kosovo became a province of the Yugoslav federation, research into and the publication of national folk heritage items, especially epic songs, was restricted. Today Albanians have studied and published dozens of volumes of collected materials in both of the major cultural centres, Tirana (the capital of Albania) and Prishtina (the capital of Kosovo). Most of them are in the Albanian language. The language barrier has prevented the Albanian epic from becoming known to the public internationally. A few good introductory monographs on the subject have, nonetheless, been published in English, among them: Albanian and South Slavic Oral Epic Poetry (1954, 1969) by Stavro Skendi (1905-89); Albanian Folk Verse, Structure and Genre (1978) by Arshi Pipa (1920-97); and most recently The Bilingual Singer: A Study of Albanian and Serbo-Croatian Oral Epic Traditions (1990) by John Kolsti. There is also the German-language Die Volksepik der Albaner (1958) by Maximilian Lambertz (1882-1963) (Elsie and Mathie-Heck 2004: xiv).

\section{Steps in the collection and study of Balkan epics}

When folklore began to be seen as an attractive field of study in the nineteenth century, the predominant ethos was informed by Romanticism, epitomised by the raising of consciousness of peoples on the basis of their ethnicity and marking out the nations as distinct from each other. This was the time when written epics emerged, their characteristically extensive form being the product of the desire of Romantics to construct national cultural identities. Until then songs about heroes and songs of praise had mainly only existed among epic singers.

Great changes were made in the study of epics in the research and work of Milman Parry and Albert Lord who, in search of the archetype of the creator of the Homeric epic, travelled to the Western Balkans and recorded the works of Bosnian bilingual singers in the Sanjak of Novi Pazar in the 1930s. They visited 
towns in Bosnia and recorded epic singers and their entire repertoires. But this was not all. They would begin by recording the whole repertoire of a singer and then those of other singers in the same region, in relation to the singer they had initially recorded. They noted every fact about the singer; apart from the repertoire, they noted the personal details of each singer, facts about their culture and the place from which they came, as well as manifold linguistic data which emerged from the recordings. Apart from the songs Parry and Lord recorded, their work also tells us the names of the singers: Qorr ('Blind') Huso, Sali Ugljanin, Avdo Međedović and so on (see Elsie and Mathie-Heck 2004). We also know about Nikola Vujnović, the local man who put the Americans in touch with the singers. It was from this time that the epic began to be seen as oral material linked with the person who sang it. ${ }^{1}$ They then began to record all the details that the singer of an epic brought to bear in his work, considering each line or displaced word a characteristic feature of his creation. Today the song does not only consist of the text, but the whole performance. The studies of Parry and Lord linked examples of epics with empirical studies on the composition and performance of oral epic (see Lord 1971, 1991)).

This change in the documentation of the epic was in part connected to the use of recording equipment. In the nineteenth century folklore had been recorded by means of pencil and paper, and all that was considered to be relevant was the text. Other elements - such as those related to the performance - were left unrecorded. For these early recordings the singers had to dictate the text to the collector, who then wrote it down, and this process certainly impacted negatively on the performance. In the twentieth century, along came audio recording equipment, the dictaphone and the tape recorder, which made possible the recording of the song, the voice, the text and the sound. Singers were able to perform the song freely, expressing themselves to the full. In 1954, Stavro Skendi wrote in his book Albanian and South

1 In the Visaret e Kombit (first published in 1938, it is notable that the collectors were conscientious in collecting the folklore as accurately as possible. Beside the text there appears the name of the singer and a few contextual details in connection with the events described in the song. This shows that the authors of Visaret e Kombit may have been aware of contemporary methods of folklore collection. See Palaj and Kurti 2005 and Zheji 1998: 24.
Slavic Oral Epic Poetry that whilst today, recordings are made on tape, 'We should take another step, so we might have the text and the music, the singer and the audience, as well as the surroundings in the same place, in a film that talks and sings. All these elements are necessary for a profound evaluation of epic oral poetry' (Skendi sa: 36$).^{2}$

Lauri Honko divides the development of the study of the epic into three phases:

1. The pretextual phase, based on content, information contained in the text, but not the text itself or its form or boundaries (Honko 1998b: 44).

2. The 'text is king' phase, when the new academic discipline of folklore began (in the nineteenth century), which was based on epics recorded in written form. The invention of the historic-geographical method greatly assisted in this, making the analysis of variants possible.

3. The 'performance is king' phase, based on the study of oral discourse (morphology and poetics), the analysis of performance, the analysis of context, the study of understanding, ethnic and intracultural categorisation and the different positions of systems (functionalisation, ecology, structuralisation etc.). (Honko 1998b: 46)

The historic-geographical method emphasised recorded variants and multiple publications of the same song. This brought about the acceptance of the variant, which today is considered to be one of the main features that distinguish oral culture from the written forms. While the written text has only one form, the oral text exists in many forms because it exists within oral culture and as such differs from one performer to the next. Each of its forms, that is to say each of its variants, contains its own distinctive details and so each variant must be analysed and studied separately.

What makes the variants of a particular epic song interesting to the scholar, besides the text, is the context. ${ }^{3}$ According to Honko the verbal element is only

2 Albanian and South Slavic Oral Epic Poetry was translated into Albanian by Xhevat Lloshi and it is titled Poezia epike gojore e shqiptarëve dhe e slaveve të jugut (sine anno) and I am here referring to this Albanian translation.

3 The first contextual studies in folklore were made by the American folklorists Richard Bauman, Américo Paredes, Dan Ben-Amos, Alan Dundes etc. 
a part of the text, not its entirety. The text must include many other things connected with the verbal/ non-verbal relationship between the performance and the audience, among them gestures, body language, use of space, and props (instruments, ritual objects). To 'read' the verbal text in its entirety we need two documents: 1) a 'performance record'; and 2) a 'performance report.' The first is the text, the oral material recorded, while the second comprises the elements that cannot be presented, such as the history of the performer, contextual information, cultural histories, types of genre and so on (Honko 2000: 13). Every performance of folklore transmitted orally is unique and needs to be studied in full.

The textualisation of folklore is a complex process. The data comes to us from various informants in different historical periods, from different collectors, with differing levels of education and with differing motives for publishing oral material.

\section{Documentation of the Albanian epic}

The documentation of the Albanian oral epic tradition began with a non-Albanian publication by an Austrian Albanologist, Gustav Meyer. In his book Albanesische Studien (6 vols), published in Vienna in 1897, he included fifteen lines (a fragment) of an Albanian epic song from the cycle concerning the brothers Muji and Halil (Neziri 1998: 25).

At the beginning of the twentieth century some complete epic songs from 'The Cycle of the Frontier Warriors' were published. ${ }^{4}$ They were collected and edited by Albanian diaspora authors who published the materials in Albanian journals and newspapers edited abroad. This was during the period when the Albanian population was under the Ottoman rule and didn't have a right to have their own schools. People who wanted to be educated needed to study abroad. There they had contacts with different cultural institutions and groups which influenced their academic interests toward traditional culture. Epic songs and other oral forms were published not only in cultural journals but also schoolbooks written by Albanian intellectuals educated abroad.

Albania declared its independence from the Ottoman Empire in 1912. One year later its independence was recognised. A proportion of Albanian-inhabited land remained, however, outside the state borders.

4 The published materials can be found in Mbledhës të hershëm të folklorit shqiptar (1635-1912) 1962, vol. 3: $521,524,529$.
A project to produce a definitive version of the 'Cycle of the Frontier Warriors' began with the publication of fifteen volumes of Visaret e Kombit ('Treasures of the Nation'), a collection of Albanian folklore, in 1937. The first two volumes of this collection are devoted to the 'Cycle of the Frontier Warriors' (Zheji 1998: 22). After the Second World War, the project was continued by the Albanological Institute of Prishtina, which also produced a collection of twenty-five volumes of folklore. Three volumes, edited under the supervision of Anton Çetta, ${ }^{5}$ are dedicated to the 'Cycle of the Frontier Warriors'. Songs of this cycle are still being edited and published as works of individual folklorists, based on field recordings and fieldwork. Such projects include the work of Qemal Haxhihasani at the Institute of Tirana and the work carried out in Prishtina under the supervision of Zymer Neziri.

Today there is a good amount of published material from the 'Cycle of the Frontier Warriors. These publications, however, lack contextual information. They contain very little information about the creators of the songs, the historical circumstances of their creation, about the audience or any other information that would shed light on the performance.

To examine the process of documentation, I have chosen variants of one song, 'The Wedding of Ali Bajraktari.

\section{Contextual information in the publication of Albanian epic}

According to Honko, 'the performance report' is very important for the study of oral epics. It should always be accompanied by 'the performance record', since such data enables an unlocking of the context of the creation of the epic itself. In my research I look for such contextual information in the published variants of the epic song 'The Wedding of Ali Bajraktari'.

The oldest published variant of 'The Wedding of Ali Bajraktari' was published as part of the collection Visaret e Kombit, vol. 2 ('Songs of Frontier Warriors and Legends') collected and edited by Fr Bernardin Palaj and Fr Donat Kurti in Tirana in 1937. It says in the introduction 'We have before us a collection of

5 Anton Çetta (1920-95) is considered to be the founder of Albanian folklore studies in Kosovo. When the Albanological Institute in Prishtina was reopened in 1967, Çetta was head of the Department of Folklore, which started the extensive, long-term project of collecting and publishing Albanian folklore. Professor Çetta also organised field research expeditions. 
342 songs, valuable material collected at great pains by the Franciscans over nearly forty years' (Palaj and Kurti 2005: xi). The Franciscans had been, in other words, collecting Albanian folklore since the end of the nineteenth century, when there was a rise in consciousness about the elements of national culture in many countries. The Franciscans of Shkodra followed this cultural movement and, through the publication of Albanian folklore, bore witness to its value and to the place of this material alongside the folklores of the other peoples of Europe. In the introduction to the volume we find general information on the ways in which the study of folklore had developed in the world. The songs are preceded by a 'Preface' in which various aspects of the epic material are presented. Fairly comprehensive information is provided about the songs that follow, including their themes, their origin (albeit in the form of a hypothesis), the variants, the history of their publication, the characters in the songs, the identity of the collectors and the singers, the region they are from, the rhythm of the songs and the instruments with which they were sung. Furthermore, before each song the editors provide a short summary of the events described in the song, which greatly assists readers who have difficulty in understanding the linguistic characteristics of the dialect in which the songs were sung.

As with all the other songs, there is a preface to this song entitled 'The Plot' which explains the events described in the song:

Ali Bajraktari's betrothal to the daughter of the king of Kotor. He has paid the money and sets the marriage day three weeks afterwards. But in the meantime he gets sick. His fiancée waits for him for three years. After three years, she sends him a letter asking for the last time if he will marry her or not. Ali answers that he can't marry her. Then Old Man Qefanak engages her. On the day of the marriage, when friends and relatives come to take the bride and send her to the groom, they pass through Ali Bajraktari's village. The bride hears the groans of Ali's sister crying over her brother's fate. Then the bride asks the wedding guests to stop at Ali Bajraktari's house, because she wants to visit

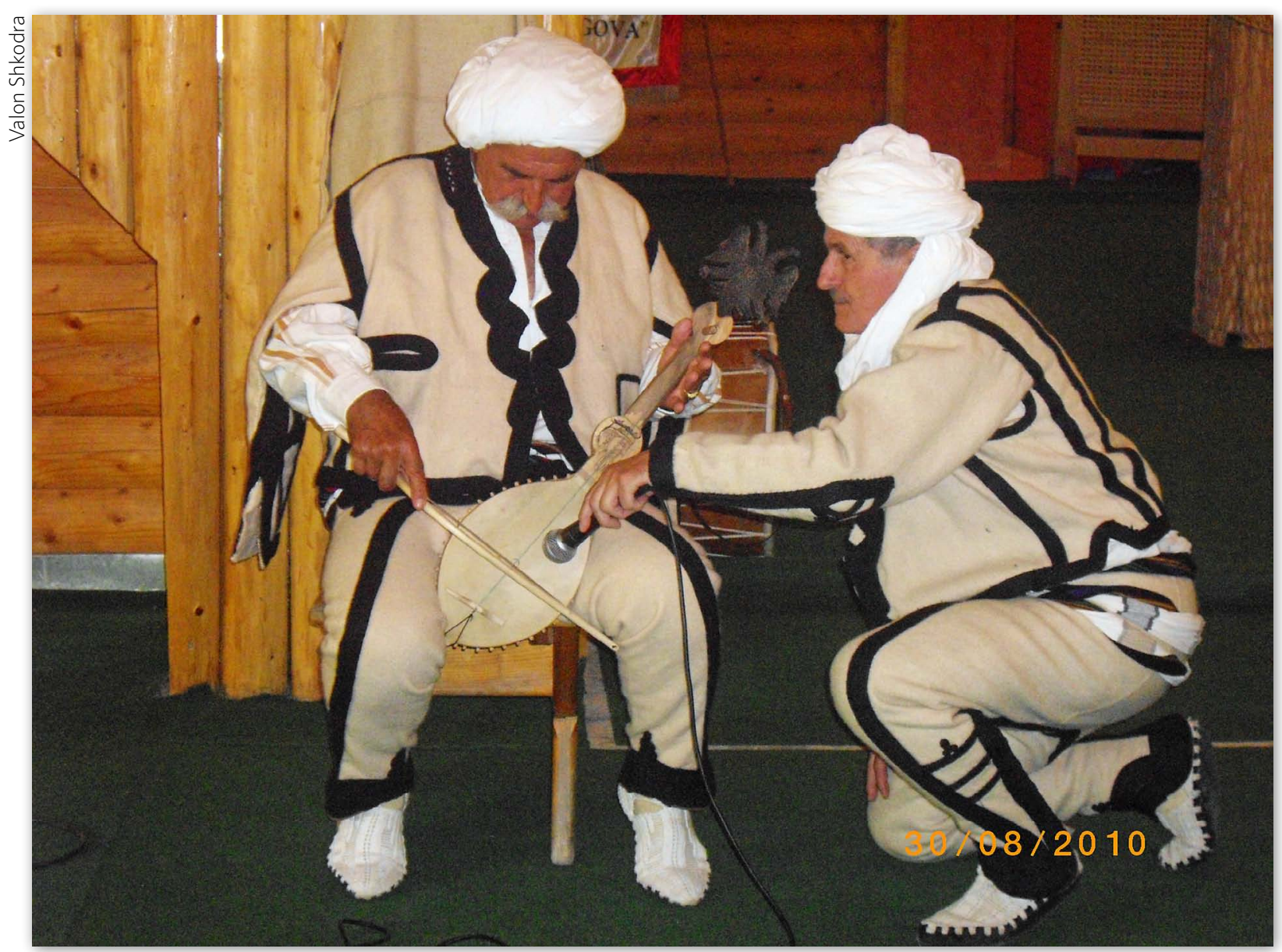

Albanian rhapsodist performing an epic song. 
him. She uses a magic spell to get into the house and cures Ali, who marries her. Then the wedding guests return to Old Man Qefanak without the bride. (Visaret e Kombit 2007: 118)

This song has 155 lines and at the end there is a note about the identity of the singer as well as his birthplace. The few facts given about this song conform to the conventions of the period at the beginning of the twentieth century.

Almost the same method of collecting and registering both reports appears in the second publication, Kangë popullore shqiptare të Kosovë-Metohis ('The Albanian Folk Songs of Kosovo and Metohia', 1952), which presents folk materials collected from among Albanians living in Kosovo, part of the Yugoslav federation at that time. The book presents the history of Albanian folklore in general, including Kosovo. The 'Introduction' goes on to give information associated with each type, concluding with some remarks about language and phonetic details that had been taken into account during the transcription of the material. As in Visaret e Kombit, the texts of the songs are summarised in standard language, while the language of the songs is that of the singer. There is an appendix in the back of the book which gives some information about the time or the place in which the song was sung. These 'Notes' give some facts about the identities and the educational levels of the collectors and which songs they collected. There is also information about each of the singers: name, age, place of birth and residence, educational level, profession and the number of songs sung. There is also information about the districts in which the songs were collected, about the dates of recording and people who assisted on the project.

'The Wedding of Ali Bajraktari' is called 'Martesa e Ali Agës' ('The Wedding of Ali Aga') in this volume. It is 144 lines long. The notes at the end of the book give us the name and affiliation of the collector, the identity, date and place of birth of the singer as well his education and skills, the place and time of recording, and also the names of the team of collectors. This early volume provides elementary facts about the oral texts and reflects the awareness of the collectors that, while the text is considered to be central, accompanying information about the singers must be provided.

When comparing the above versions with the ones that will follow, it becomes apparent that there is an increasing lack of contextual information from one edition to the next. In some way this can relate to the idea that authorship in folklore is collective and data on individuals unimportant. During the first decades of the twentieth century, the influence of Eastern Bloc methods of research dominated in Albania and Yugoslavia. As Propp claimed in his studies, folklore never has an author and this is one of its specific characteristics (Propp 1997: 6).

The subsequent publication in which this song appears dates from 1974. It was edited by Anton Çetta at the Institute of Albanology in Prishtina, Kosovo. The material published in this volume comprises not only folklore of Albanians in Kosovo, but also from Montenegro, Serbia and Macedonia. In the short introduction the general situation of the "Cycle of the Frontier Warriors' in Kosovo is presented (Çetta 1974: iii). It is stated that the epic tradition is still alive.

This volume contains 44 epic songs, transcribed according to the language of the singer. Below the title of each song is a note indicating where it was collected but no other information. At the end of the texts there is a glossary of rare words and a twopage list of all the singers, the names of their fathers, the date and place of their births, their professions, their levels of education and the number of songs each singer has sung. This information is not, however, given for every singer. After the list of singers, there follows a list of the names of collectors and the number of songs each has collected. The date and place of birth and level of education of some collectors are mentioned also. At the very end of the book, there is a two-page table of contents giving each song a number, stating the year it was recorded and the page on which it can be found. Here 'The Wedding of Ali Bajraktari' is called 'Ali Bajraktari merr Fatimen e Pashës së Vidimit' ('Ali Bajraktari Marries Fatima, the Daughter of the Pasha of Vidim'). This book follows the methods of the text-centred school of recording folkloric material, which was characteristic of academic folklore research in Yugoslavia at that time.

The next three editions came out in the years 1983, 1991 and 1993. They give the data only pertaining to the identity of the singer and the collector, as well as the place and the year when it was collected, nothing more (Epikë legjendare nga Rrethi i Kukësit 1983; Berisha et al. 1991; Çetta et al. 1993).

The process of producing traditional epic forms with the old themes, such as the battles of the frontier warriors is no longer in its creative phase. So examples of the theme are difficult to collect because they are no longer happening as events. The rhapsodists usually say that the old epic songs are hard to sing because they are very long and the theme is not 
relevant any more. Sometimes they can sing a fragment, but not the entire song. Other factors affecting the continuity of the epic include the impact of globalisation and the advent of mass literacy. The younger generation has a reduced capacity for reproducing oral epic, and less time and interest in continuing the old traditions.

Besides the 'Cycle of the Frontier Warriors' there are historical epic songs, which are based on the deeds of historical figures, the national heroes. These songs date back to medieval times and the Albanian national hero Gjergj Kastrioti (Skenderbeu), who served in the Ottoman army and fought against the Ottomans with the aim of liberating his homeland. The Albanian historical epic is filled with heroes who fought to liberate Albanian lands from foreign invaders.

Even today we can find so-called 'new' epic songs, which are created out of stories of new heroes and new battles and based on the bloody events which occurred in Kosovo 15 years ago. These songs belong to the genre of the historical epic, because of their topics, but they are shorter than the old epic songs; they glorify the heroism of young boys who are killed while protecting civilians and their homes against attacks by the Serbian army and paramilitary forces. They are not long, but the composition techniques follow the old ones used in singing of the old frontier warriors. The heroes are new and the events are fresh, but the singing model is old. As Zymer Neziri writes, these songs present the latest cycle of the Albanian historical epic, reflecting the epic motifs of magnificent scenery as well as the display of sublime feelings about the sacrifice of the blood spilled by the young heroes who struggled for national liberation (Neziri 2008: 170).

\section{The growing importance of contextual information}

The latest publication of 'The Wedding of Ali Bajraktari' contains some contextual information. This song is found in the collection of 'Songs of the Frontier Warriors' of the lahuta-player Haxhi Meta-Nilaj, collected and edited by the Albanian folklorist Zymer Ujkan Neziri, Epika legjendare e Rugovës ('The Legendary Epic of the Rugova Region, vol. 5, 1997). This is the first time that Albanian epic songs have been published according to a singer's repertoire rather than on a thematic basis. The song about the wedding of Ali Bajraktari, called 'Ali Bajraktari dhe çika mejdanxhi' ('Ali Bajraktari and the Girl of the Battleground') is 221 lines long and describes the wedding of Ali Bajraktari to the daughter of the old man
Mehmet Aga. Before the girl is married, she appears dressed as a man and kills a sea giant in a duel, so defending her honour and that of her elderly father. On the evening before her duel with the sea giant, she spends time disguised as a man at the house of Ali Bajraktari, skilfully hiding her identity. While there, he (she) promises Ali, the frontier warrior, that he (she) will survive the duel and come to the wedding as a friend. She marries Ali Bajraktari on the day appointed after having explained to him that she was indeed the 'friend' who had killed the sea giant.

Apart from the song's text, attention is paid also to the performer, the singer Haxhi Meta-Nilaj, who accompanied himself on the lahuta. After a brief introduction, the editor continues with a detailed biography of the singer and gives the particulars of the region he comes from - altogether almost six pages. It starts with the geography and history of the village and the wider area, continues then with particulars of the families and older generations who were killed in conflicts with neighbouring Montenegrins. There is also information about the religious identity of the singer and other facts distinctive of the local people: pagan rites, various rituals, initiation rites, the dialect spoken in the area, traditional costumes, and the songs and dances still performed. There is also a piece on the life of Haxhi Meta-Nilaj's close family, his way of life, his personality, character and honour as a lahuta-player, accompanied by a photograph of the singer and a map of the area.

\section{Conclusion}

Examining the published examples of 'The Wedding of Ali Bajraktari' and analysing them from the viewpoint of the question concerning the textualisation of oral epic, it is safe to say that the Albanian epic can be located in what Honko calls the second phase; that with the 'text at the centre'. Albanian authors have been concerned with the text only, not with the context or performance. This, however, is not entirely the case. It was general nationalistic ideology that determined whether the material was to be published and whether the identity of a singer was disclosed or not. This can clearly be discerned from the publications examined in this paper. Exceptions to this rule are the volumes of epic songs published after the fall of communism, under the supervision of Zymer Neziri. The publication of the epics is an ongoing process while the epic song continues to have an active life in the mountainous areas of Kosovo, especially as a method of singing. 
Albanian epic, rich in themes and stylistic features and artistic expression as well as rich in verse, although collected as literary text, lacks data on its performance and as such remains deficient in documentation. But the opportunities for finding its themes, as well as the techniques of its formation, which are still active in the field, make possible the reconstruction of the socio-cultural context of old songs while analysing the current context of creating oral epics.

In the examination of 'The Wedding of Ali Bajraktari, a clear pattern emerges of the changes in how Albanian folklorists have operated in relation to the field, moving from a generalised, 'anonimised' conception of 'the people' towards an idea of the importance of the individual informant and the social and anthropological background of the performance.

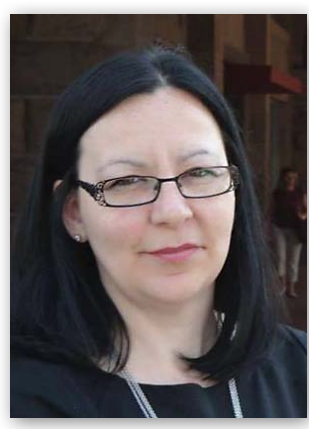

Arbnora Dushi is research associate at Folklore Department of the Institute of Albanology in Prishtina, Kosovo. Her interests are focused on observing Albanian folklore within the scope of modern research and the study of the methodology of folklore. She has published several books on Albanian folklore. Email: arbnoradushi(at)hotmail.com

\section{Bibliography}

Berisha, Rrustem, Sadri Fetiu, and Adem Zejnullahu (eds) 1991. Këngë kreshnike, vol. 2 (Prishtina, Instituti Albanologjik i Prishtinës)

Çetta, Anton (ed.) 1974. Këngë kreshnike, vol. 1 (Prishtina, Instituti Albanologjik i Prishtinës)

Çetta, Anton, Fazli Syla, Myzafere Mustafa, and Anton Berisha (eds) 1993. Këngë kreshnike, vol. 3 (Prishtina, Instituti Albanologjik i Prishtinës)

Elsie, Robert, and Janice Mathie-Heck 2004. Songs of the Frontier Warriors (Wauconda, IL, Bolchazy-Carducci Publishers, Inc.)

Epikë legjendare nga Rrethi i Kukësit 1993. Epikë legjendare nga Rrethi i Kukësit (Tirana, Instituti i Kulturës Popullore, Akademia e Shkencave e RPS të Shqipërisë)

Foley, John Miles 2005. 'Introduction' in A Companion to Ancient Epic, ed. John Miles Foley (New York, Blackwell Publishing)

Graziosi, Barbara, and Johannes Haubold 2005. Homer: The Resonance of Epic (London, Duckworth)

Haxhihasani, Qemal 1991. 'Mendësi zotëruese në Ciklin e Kreshnikëve' in Gjurmime Albanologjike, seria folklor dhe etnologji 21 (Prishtinë, Instituti Albanologjik)

Honko, Lauri 1998a. 'Introduction: oral and semiliterary epics' in The Epic: Oral and Written, ed. Lauri Honko,
Jawaharlal Handoo and John Miles Foley (Mysore, Central Institute of Indian Languages)

-1998b. Textualising the Siri Epic, FF Communications 264 (Helsinki, Academia Scientiarum Fennica)

-2000. 'Introduction' in Thick Corpus, Organic Variation and Textuality in Oral Tradition, ed. Lauri Honko, Studia Fennica Folkloristica, 7 (Helsinki, SKS)

Kolsti, John 1990. A Study in Albanian and SerboCroatian Oral Epic Traditions, Harvard Dissertations in Folklore \& Oral Tradition, (New York, Garland Publishing Inc.)

Lord, Albert B. 1971. The Singer of Tales (New York, Atheneum)

-1991. Epic Singers and Oral Tradition (London, Cornell University Press)

Mbledhës të hershëm të folklorit shqiptar (1635-1912), vol. 3 1962. Mbledhës të hershëm të folklorit shqiptar (1635-1912), vol. 3 (Tirana, Instituti i Folklorit)

Neziri, Zymer Ujkan 1997. Epika legjendare e Rugovës, vol. 5 (Prishtina, Instituti Albanologjik i Prishtinës)

-1998. 'Gustav Majeri dhe fillet e botimit të këngës kreshnike shqiptarei in Gustav Majer (Gustav Meyer) (Prishtina, Instituti Albanologiik i Prishtinës)

-2008. Studime për folklorin vol. 2 (Prishtina, Instituti Albanologjik i Prishtinës)

Palaj, Bernardin, and Donat Kurti (eds) 2005. Visaret e Kombit: Kangë Kreshnikësh dhe Legjenda, 2nd edn (Shkodra, Botime Françeskane)

Propp, Vladimir 1997. Theory and History of Folklore, trans. A. Y. Martin and R. P. Martin, ed. A. Liberman, $4_{\text {th edn (Minneapolis, University of Minnesota Press) }}$

Skendi, Stavro sa. Poezia epike gojore e shqiptarëve dhe e sllavëve të jugut, trans. Xhevat Lloshi (Tirana, Instituti i Dialogut dhe i Komunikimit)

Uçi, Alfred 1986. 'Epika heroike dhe roli i saj në folklorin shqiptar' in Çështje të folklorit shqiptar, vol. 2 (Tiranë, Akademia e Shkencave e RPSSH)

Zheji, Gjergj 1998. Folklori shqiptar (Tirana, Argeta-LMG) 